\title{
Volatile oil contents of ashe and redberry juniper and its relationship to preference by Angora and Spanish goats
}

\author{
RICHARD R. RIDDLE, CHARLES A. TAYLOR, JR., M.M. KOTHMANN, AND J.E. \\ HUSTON
}

\begin{abstract}
Auhors are former graduate student, Department of Rangeland Ecology and Management, Texas A\&M University, College Station, Tex. 77843; superintendent, Texas Agricultural Experiment Station-Sonora, PO Box 918, Sonora, Tex, 76950; professor, Department of Rangeland Ecology and Management, Texas A\&M University, College Station. Tex 77843-2126; professor, Texas A\&M Research and Extension Center-San Angelo, Tex. 76901.
\end{abstract}

\begin{abstract}
Angora and Spanish goats (Capra bircus) were exposed to ashe (Juniperus ashei Buchholz) female, ashe male, redberry (Juniperus pinchotti Sudw.) female and redberry male branches in cafeteria style feeding trials. Preferences were consistent across seasons (except winter). Spanish goats generally consumed more juniper than Angoras. Both breeds preferred ashe over redberry juniper and female over male plants. Concentrations of volatile oils varied significantly between species of juniper and among seasons, but not between sexes. Concentrations of total oils were greater in the spring and summer than in the fall and winter. Concentrations of sabinine $+\beta$-pinene were greater in redberry than ashe for all seasons. Concentrations of myrcene were significantly greater for redberry during the spring and summer. Significant correlation of oil concentration with grams of juniper consumed indicated that specific oils were influencing preference for juniper. Correlations were similar for Angora and Spanish goats, indicating no differences between goat breeds in sensitivity to oils.
\end{abstract}

Key Words: goats, Edwards Plateau, Juniperus ashei, Juniperus pinchotii, secondary plant chemicals, preference

The increase of juniper (Juniperus spp. L) in the Edwards Plateau region of south-central Texas over the past hundred years has reduced forage production for grazing animals. Juniper is considered unpalatable for grazing animals. Observations indicate that redberry is less palatable than blueberry. Vegetation growth beneath the juniper canopy is reduced (Smeins 1990). Juniper growth in the presence of desirable range flora may cause the mortality of the more desired species with time (Rykiel and Cook 1986).

Suppression of naturally occurring fires and severe overgrazing have promoted shrub invasion (Youngblood and Cox 1922,

Authors wish to thank Ray Hinnant and Sue Engdahl for their assistance with statistical analyses and gas chromatography.

Technical Article TA 31727 from the Texas Agricultural Experiment Station.

Manuscript accepted 6 May 1995.
Smeins 1980). These factors, along with recurrent droughts, encouraged the growth of ashe and redberry junipers (Smeins 1990). These conditions continue to plague the area (Smeins and Merrill 1988), and juniper invasion has become the most crucial ecological and economical range management issue on the Edwards Plateau (Smeins 1990). Once canopy closure occurs, it is nearly impossible to decrease juniper density except by fire (Bryant et al. 1983) or expensive mechanical and chemical methods (Young et al. 1982). However, goat browsing can reduce juniper density and canopy cover (Fuhlendorf 1992). Both Angora and Spanish goats are important to the ranching industry in the Edwards Plateau.

Volatile oils are a class of secondary compounds produced by some plants as defense mechanisms against grazing, thus ensuring survival of the plant (Barry and Blaney 1987). Total volatile oil content and concentration of individual oils vary according to maturity, species, and site factors (Maarse and Kepner 1970, Jobman 1972, Tucker et al 1976). However, the occurrences of specific oils within a plant are consistent (Nagy and Regelin 1977). It is important to understand relationships of volatile oil content and juniper consumption by goats.

For this study, we hypothesized that preference for juniper was correlated with concentrations of specific volatile oils in juniper. Our objectives were to 1) determine relative preference between the 2 species and sexes of juniper, 2) relate preference for juniper to concentrations of specific volatile oils, and 3 ) determine if total volatile oil content and concentration of individual oils in juniper vary with season or species and sex of plant. We evaluated the seasonal preferences of Angora and Spanish goats for male and female plants of ashe and redberry juniper and correlated volatile oil concentrations with preference for juniper.

\section{Materials and Methods}

\section{Experimental Area}

The study was conducted at the Texas A\&M Agricultural Experiment Station (TAES) located 45 miles km southeast of Sonora, Texas $\left(31^{\circ} \mathrm{N} ; 100^{\circ} \mathrm{W}\right)$. The 1,377 ha research station is 
situated on the border of Sutton and Edwards counties within the Edwards Plateau region of south-central Texas (Hatch et al. 1990). It was established in 1916 to conduct sheep and goat research. The elevation of the research station is about 632 meters. The region is predominantly rangelands composed of a mixture of grasses, forbs, and woody species. Warm summers and mild winters allow for an average growing season (March through October) of 240 days. Precipitation is highly variable with long-term average precipitation (1918-1988) of $60.9 \mathrm{~cm}$ and median annual precipitation of $43.9 \mathrm{~cm}$. The large difference between the mean and median precipitation is the result of frequent droughts and occasional very wet years. Peak precipitation months are May, June, and September. Growing season precipitation averaged $40.9 \mathrm{~cm}$ over 70 years (Taylor et al. 1993).

The most common soils on the station are Tarrant silty clay and Tarrant stony clay (members of the clayey-skeletal, montmorillonitic, thermic family of Lethic Haplustalls), with some Kavett silty clay soils in low-lying areas (Taylor et al. 1993). The Tarrant stony clays are the dominant soils which overlay a fractured limestone substrate and are generally 15 to $30 \mathrm{~cm}$ deep. These soils contain 5 to $70 \%$ limestone fragments or slabs of limestone outcroppings. The topography is typified by rolling, stony hills with slopes of 3 to $4 \%$ which produce patterns of shallow divides, limestone outcrops, and low lying areas of deeper soils (USDA-SCS 1972).

The vegetation is a mosaic of juniper and oak mottes interspersed with mid and short grasses. For a complete description of the climate, soils, and vegetation at the research station see Smeins et al. (1976).

\section{Animals}

Ten Angora goats and 10 Spanish goats of the same sex (female) and age ( 1 year) were used in this study. Each goat was identified with an ear tag and fed a pelleted maintenance ration for the duration of the preference trials. The contents and percent (\%) composition of this ration were as follows: sun cured alfalfa $30 \%$, cottonseed hulls- $19.2 \%$, cottonseed meal- $17 \%$, corn- $26 \%$ molasses-5\%, trace mineral salt-1\%, ground limestone-1\%, ammonium chloride- $0.6 \%$, urea- $0.2 \%$, rumensin- $30 \mathrm{~g} / \mathrm{ton}$.

Before all trials, the animals underwent a preconditioning period of several days in which they were exposed to the trial area and to juniper branches. This was to reduce stress and variation in appetite due to sudden changes in diet, new surroundings, and exposure to novel food sources. The animals were not fasted prior to preference trials or at any time during the study.

\section{Shrub Selection and Collection}

Juniper branches were collected from pastures on the station where unbrowsed ashe and redberry juniper were found in abundance. Field observations indicated that in heavily goated pastures, ashe juniper plants were almost always browsed, whereas redberry junipers were not. It was also noted that there were not enough mature redberry trees within the grazing exclosure to provide branches for the duration of the sampling period. Therefore, ashe juniper samples were collected from an exclosure pasture which had not been grazed by livestock since 1949 , and redberry juniper was collected from pastures which had been grazed. This method of sampling was used to reduce bias related to browsing history of the juniper plant.

Juniper trees were placed in 4 groups according to species and sex: ashe female, ashe male, redberry female, and redberry male. Five mature trees of uniform size from each species and sex were identified with flagging tape, and trees from each of the 4 groups were numbered 1 through 5 . These trees were selected on the basis of size and amount of foliage. The terminal $1.5-2.0 \mathrm{~m}$ of tree branches were clipped from each tree. Only trees having foliage within $1.5 \mathrm{~m}$ of the ground were used. This height ensured that the foliage collected was within the natural browse line of the animals used in this study.

\section{Preference Trial}

Preference trials consisted of 10 minute challenge bouts repeated 3 times per day for 10 consecutive days. Preference was determined between the 2 juniper species and sexes by the amount of forage consumed during each trial. The same animals and trees were used for all trials.

At least 2 large branches from each of the 4 tree groups were clipped from trees bearing the same number during the morning on each day of the trial. Each of the numbered trees (1-5) from the 4 groups was tested for preference on consecutive days during the 10-day trial period. The first 2 days of the trial tested all the trees numbered 1 , the next 2 days all trees numbered 2 , and so on. The branches were kept in a cool, dry place until ready for use. As the branches were clipped from the trees, on days $1,3,5,7$, and 9, a sample of foliage $5-10 \mathrm{~cm}$ in length was immediately frozen in liquid nitrogen and then transferred to an ultra-cold freezer $\left(-70^{\circ} \mathrm{C}\right)$ for future volatile oil analysis.

Small branches about $0.5 \mathrm{~m}$ in length were separated from the larger branches and weighed individually. One branchlet from each juniper category was then placed in 1 of 4 slots on a specially designed holder. This holder was constructed from 2" $\times 4$ "s 15 inches long and centrally mounted on $3 / 4$ " plywood sections measuring $15^{\prime \prime} \times 6^{\prime \prime}$. Four equally spaced 1 " diameter holes were bored through the surface of the $2^{2} \times 4^{\prime \prime}$ s to hold the 4 juniper branchlets. Branchlets were secured by a nail to prevent their removal during trials. Holders were wired to pens to stabilize the entire fixture.

Five animals from each breed were placed in individual pens measuring $1.5 \times 5 \mathrm{~m}$ and presented the holders with juniper branchlets. Animals were allowed 10 minutes to browse juniper branchlets from each holder. All branchlets were then collected and reweighed to determine grams of juniper consumed. New branchlets were clipped, weighed, and recorded for the next trial. This process was repeated 3 times each day for the 10-day trial period. On the odd numbered days, 5 goats from each breed (10 total) were used and on even numbered days the other half of the goats were used. Therefore, a total of 30 individual goat measurements were collected per day, and each goat was tested with each tree.

Grams consumed were calculated by taking the difference between the beginning and ending branchlet weights and adjusting for moisture loss. Moisture loss was estimated for each trial from the weight of 2 unbrowsed branchlets.

\section{Determination of Volatile Oil Concentration}

Volatile oil concentration was measured for each species and sex of juniper. Frozen ( $15 \mathrm{~g}$ fresh weight) samples of juniper were added to $150 \mathrm{ml}$ of distilled water in a modified Clevenger (1928) distillation apparatus and steam distilled for 8 hours, and the distillate collected in $5 \mathrm{ml}$ of hexane. Samples $(2 \mathrm{ml})$ of distillate were drawn and $2 \mu \mathrm{l}$ of tetradecane were added as an internal standard. Distilled samples were stored at $-50^{\circ} \mathrm{C}$ until they could be analyzed.

Analysis was performed on a HP579A gas chromatograph, 
peak areas were measured with a HP3394 integrator, and terpenes were identified by comparison of known retention times of external standards (Straka 1993). The following standards were used: $\alpha$-pinene, camphene, sabinene, $B$-pinene, myrcene, cymene, limonene, camphor, terpineol, carvone, and bornyl acetate. Sabinene and B-pinene did not separate adequately for accurate identification (Maarse and Kepner 1970) and were therefore combined for analysis.

\section{Statistical Analysis}

Independent variables were seasons (fixed), goat breeds (fixed), species of juniper (fixed), sex of juniper (fixed), tree within species and sex (random), and individual animals (random). The dependent variable was grams consumed. Animals were fed individually and considered replicates. Data were averaged across trials within day's and across days prior to analysis. Data were first analyzed using a full model including season. Because significant interactions existed between season and other main effects, reduced models (Table 1) were analyzed within seasons. Mean values were considered significantly different when the alpha probability was less than or equal to 0.05 .

Volatile oil concentrations were analyzed using ANOVA (Table 2). Independent variables were seasons (fixed), individual trees (random), sex (fixed), and species (fixed). Because signifi-

Table 1. Analysis of variance model with mean squares, coefficients of determination $\left(R^{2}\right)$, and coefficients of variation $(C V)$ for preference $(g$ consumed trial) trials during the 4 seasons of 1991 using Angora and Spanish goats ( $G B=$ goat breed, $G N=$ individual goat) selecting from male and female ( $\mathrm{SX}=$ sex) ashe and redberry junipers ( $\mathrm{SP}=$ species) collected from 5 trees ( $T R=$ tree) for each species and sex of juniper.

\begin{tabular}{|c|c|c|c|c|c|}
\hline \multirow[b]{2}{*}{ Source ${ }^{2}$} & \multicolumn{5}{|c|}{ Mean square } \\
\hline & $\mathrm{df}$ & Spring & Summer & Fall & Winter \\
\hline Total & 399 & & & & \\
\hline $\mathrm{GB}^{3}$ & 1 & $30001^{* *}$ & $23265^{* \neq}$ & $15471^{* * *}$ & 932 \\
\hline$G N(G B)^{3}$ & 18 & $835^{* *}$ & 567 & $311^{* *}$ & $726^{* *}$ \\
\hline$S X^{3}$ & 1 & $3177^{* *}$ & $3540^{* *}$ & $3985^{* *}$ & 434 \\
\hline $\mathrm{GB} \approx \mathrm{S} \mathrm{X}^{3}$ & 1 & $1310=$ & $935 *$ & 1 & 478 \\
\hline $\mathrm{SP}^{*}$ & 1 & $87374 * *$ & $74921 *$ & $83050^{\circ \neq}$ & $216714 \div$ \\
\hline$G B * S P^{3}$ & 1 & $9666^{* 2}$ & 17044 & $12272 \div$ & $892 *$ \\
\hline$S X^{*} S^{3}$ & 1 & 2391 ** & 1 & 141 & $2094 * *$ \\
\hline$G B=S X^{*} S P^{3}$ & 1 & 4 & 590 & 42 & 436 \\
\hline$G N * S X * S P *(G B)$ & 54 & 156 & 246 & 124 & 245 \\
\hline $\operatorname{TR}\left(\mathrm{SX}^{*} \mathrm{SP}\right)$ & 16 & $2148^{* *}$ & $2632^{* * *}$ & $1522^{* * *}$ & $2318 * *$ \\
\hline$G B * T R\left(S X^{\neq} S P\right)$ & 16 & $506^{*-1}$ & 389 & 176 & 182 \\
\hline Residual & 288 & 149 & 163 & 109 & 224 \\
\hline Model $\mathrm{R}^{2}$ & & $.82 * *$ & $.80^{* * *}$ & $.83 * *$ & $.82 *$ \\
\hline $\mathrm{CV}$ & & $45 \%$ & $53 \%$ & $48 \%$ & $34 \%$ \\
\hline
\end{tabular}

$* * \pi$ Significant at the 0.05 and 0.01 levels, respectively.

IType III mean squares.

${ }^{2}$ Goat bred was tested with GN (GB) as error term.

${ }^{3}$ Error used was $G N^{\star} \mathrm{SX} \approx \mathrm{SP}(\mathrm{GB})$.

cant season by species interactions were observed for sabinene+B-pinene, myrcene, and total oils, analyses for these oils were conducted within season.

A correlation matrix was developed using Spearman's correlation to examine the relationships between concentrations of individual volatile oils across seasons. Correlations were also examined for concentrations of individual volatile oils with grams consumed by goat breed. Stepwise regression was used to evaluate the relationship of grams consumed with individual and total volatile oils of both species of juniper across seasons and within seasons for Angora and Spanish goats.

\section{Results and Discussion}

\section{Preference}

\section{Goat Breed (Angora vs Spanish)}

Goat breed was highly significant for 3 seasons, but not during winter (Table 1). These results validate observations that Spanish goats consume juniper more readily than Angora goats (Table 3). The high genetic selection intensities placed on Angoras for mohair production may have caused them to be more sensitive to dietary and environmental changes (Huston 1991). Spanish goats are more rugged than the Angora and tend to be more aggressive browsers (Merrill and Taylor 1976, Bryant et al. 1979, Warren et al. 1984, Taylor 1985).

\section{Goats within Goat Breed}

Significant differences among individual animals within goat breed were observed for all seasons (Table 1). However, the variation among goats within breed was much less than the variation between breeds for spring, summer, and fall. Animal preference for certain species and degree of use on individual plants are factors that may influence selection by goats (Owens et al. 1992).

\section{Sex}

Sex of juniper was highly significant during spring, summer, and fall of 1991 (Table 1). In almost all cases, female junipers were selected over males (Table 3). Morphological variations between the sexes were probably the cause for these differences in consumption since no significant differences in volatile oil concentration were found (Table 2). During the spring, summer, and fall, berries were present on the female plants and small cones were present on the male plants. As the season progressed, the berries grew in size. During winter, few of the berries and cones were present. The presence of berries on female branches offered during the trials either promoted consumption and/or the presence of cones discouraged consumption.

\section{Species.}

Selection for juniper species was found to be highly significant during all seasons (Table 1). Goats consumed 3 to 5 times more ashe than redberry juniper (Table 3). Differences in the volatile oil composition and concentration between the 2 species (Table 4) probably allowed the goats to distinguish between them by smell. The senior author noted that the aroma of ashe juniper was "pleasant and fresh" compared to a more pungent odor for redberry.

Goat breed by species interaction was observed for all seasons (Table 1). Spanish goats consumed nearly double the amount of ashe juniper as Angora goats during all seasons except winter (Table 3). Spanish goats consumed more redberry than Angora during spring, summer, and fall, but the differences were less for the ashe juniper. During the winter, consumption by Angoras increased to levels equivalent to Spanish goats. Level of consumption across seasons appeared to be related to volatile oil composition and concentration. This will be discussed later.

A significant interaction between sex and species was observed 
Table 2. Analysis of variance model with mean squares, coefficients of determination $\left(R^{2}\right)$, and coefficients of variation (CV) for volatile oil concentrations during the 4 seasons (SN) of 1991 using individual (TR=trees) male and female $(S X=s e x)$ ashes and redberry junipers (SP=species) at the Sonora Research Station.

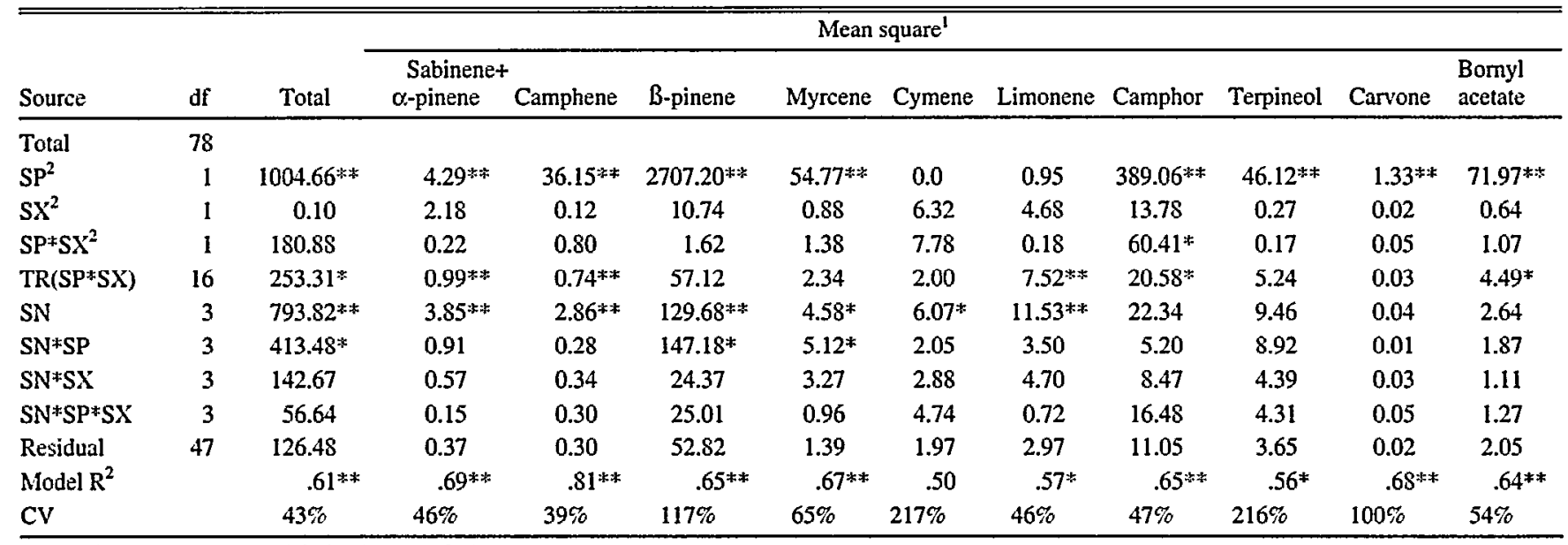

\#*\#Significant at the 0.05 and 0.01 levels, respectively.

'Type In mean square.

2TR(SP*SX) was used as enor term to test $S P, S X$, and $S P \neq S X$.

during the spring and winter (Table 1). During the spring, Angora goats ate more female than male juniper of both species; whereas, Spanish goats ate more female ashe juniper but not redberry (Table 3). During winter, consumption of male and female ashe juniper did not differ between goat breeds, but Spanish goats ate more redberry female than male. The cause of these interactions was not identified. Although seasonal variations were observed, as evidenced by these interactions, it can be concluded from these trials that the general preference ranking of Angora and Spanish goats for juniper was ashe female $>$ ashe male $>$ redberry female $>$ redberry male. Straka (1993) also found this same order of preference for cattle and sheep.

\section{Tree(Sex:Species)}

Preference varied significantly among trees within sex and species for all seasons (Table 1). Gershenzon and Croteau (1991) suggest that these differences in preference could be due to environmental and physical factors such as light intensity, temperature, soil nutrients, and water availability. These factors have been reported to affect oil composition and concentration; thus, variations in composition and concentration of individual oils should also be considered (Bryant et al. 1991). Oil content and concentrations could also vary by growth stage and plant parts within growth stages (Reichardt et al. 1984). Significant differences among trees within sex and species were noted for several volatile oils (Table 2).

\section{Volatile Oils}

All volatile oils concentrations are expressed on a fresh weight basis; thus, variations in moisture content would affect these values. However, the objective of this study was not to determine absolute values for volatile oil concentrations but to examine the relationship between oil concentrations and preference. We feel that the procedures were valid for the objectives of this study.

\section{Species}

Species of juniper was highly significant for total oils and all of the oils identified except cymene and limonene (Table 2). Ash juniper had higher levels of camphene, camphor, carvone, and bornyl acetate; whereas, redberry had higher levels of total oils,

Table 3. Means grams of juniper consumed during a 10 minute preference trial as affected by species, sex, and goat type for 4 seasons during 1991 at the Sonora Research Station.

\begin{tabular}{|c|c|c|c|c|c|c|c|c|}
\hline \multirow[b]{2}{*}{ Tree Type } & \multicolumn{2}{|c|}{ Spring } & \multicolumn{2}{|c|}{ Summer } & \multicolumn{2}{|c|}{ Fall } & \multicolumn{2}{|c|}{ Winter } \\
\hline & Angora & Spanish & Angora & Spanish & Angora & Spanish & Angora & Spanish \\
\hline \multirow{2}{*}{\multicolumn{9}{|c|}{ Ashe }} \\
\hline & & & & & & & & \\
\hline Female & $31.4^{\mathrm{b}}$ & $62.3^{\mathrm{b}}$ & $29.5^{b}$ & $52.3^{\mathrm{a}}$ & $28.1^{\mathrm{b}}$ & $52.1^{\mathrm{b}}$ & $62.3^{3}$ & $68.4^{3}$ \\
\hline Male & $24.7^{3}$ & $48.0^{\mathrm{a}}$ & $17.9^{3}$ & $51.7^{2}$ & $21.1^{a}$ & $44.1^{a}$ & $64.8^{3}$ & $70.8^{3}$ \\
\hline Mean & $28.0^{*}$ & $55.2^{x}$ & $23.7^{x}$ & $52.0^{x}$ & $24.5^{x}$ & $48.1^{5}$ & $63.6^{x}$ & $69.6^{x}$ \\
\hline \multicolumn{9}{|l|}{ Redberry } \\
\hline Male & $18.8^{\mathrm{a}}$ & $14.6^{a}$ & $9.6^{a}$ & $13.7^{3}$ & $6.2^{\mathrm{a}}$ & $9.0^{a}$ & $3.9^{\mathrm{a}}$ & $6.0^{2}$ \\
\hline Mean & $20.0^{y}$ & $20.1^{y}$ & $8.3^{y}$ & $15.8^{y}$ & $9.4^{\mathrm{y}}$ & $11.6^{y}$ & $6.8^{3}$ & $8.2^{y}$ \\
\hline
\end{tabular}

-Means for sex in same column not followed by same letter within season, goat breed and species differed significantly ( $\mathrm{P}<0.05)$.

${ }^{87}$ Means for species across sex in same column not followed by same letter within goat breed and seasons differed significantly $(\mathrm{P}<0.05)$. 
Table 4. Mean concentrations ( $\mu \mathrm{g} / \mathrm{g}$ twig) of 10 volatile oils found in ashe and redberry junipers averaged across 4 seasons and for the 4 seasons averaged across species during 1991 at the Sonora Research Station.

\begin{tabular}{|c|c|c|c|c|c|c|}
\hline \multirow[b]{2}{*}{ Oils } & \multicolumn{2}{|c|}{ Species } & \multicolumn{4}{|c|}{ Season } \\
\hline & Ashe & Redberry & Spring & Summer & Fall & Winter \\
\hline & \multicolumn{6}{|c|}{ (1) } \\
\hline$\alpha$-pinene & $0.37^{4}$ & $0.52^{\mathrm{b}}$ & $0.43^{y}$ & $0.65^{x}$ & $0.37^{\mathrm{y}}$ & $0.31^{2}$ \\
\hline Sabinene $+B$-pinene & $0.18^{a}$ & $4.02^{\mathrm{b}}$ & $2.11^{x y}$ & $3.25^{\mathrm{x}}$ & 1. $46^{y}$ & $1.49^{y}$ \\
\hline Myrcene & $0.34^{a}$ & $0.89^{b}$ & $0.69^{\mathrm{x}}$ & $0.77^{x}$ & $0.43^{\mathrm{y}}$ & $0.55^{x y}$ \\
\hline Cymene & $0.22^{a}$ & $0.21^{a}$ & $0.17^{y}$ & $0.49^{x}$ & $0.11^{y}$ & $0.09^{y}$ \\
\hline Camphor & $3.10^{3}$ & $1.61^{\mathrm{b}}$ & $2.84^{x}$ & $2.24^{y}$ & $2.16^{y}$ & $2.13^{y}$ \\
\hline Terpincol & $0.04^{\mathrm{a}}$ & $0.56^{\mathrm{b}}$ & $0.51^{x}$ & $0.50^{x}$ & $0.09^{x}$ & $0.10^{x}$ \\
\hline Carvone & $0.09^{a}$ & $0.01^{\mathrm{b}}$ & $0.07^{x}$ & $0.06^{x}$ & $0.04^{x}$ & $0.03^{x}$ \\
\hline Bomyl acetate & $1.2 \mathrm{I}^{*}$ & $0.56^{\mathrm{b}}$ & $1.05^{x}$ & $0.90^{\mathrm{x}}$ & $0.75^{x}$ & $0.88^{x}$ \\
\hline Total & 7.52 & 9.81 & 9.88 & 10.96 & 6.98 & 6.85 \\
\hline
\end{tabular}

"Means in same row not followed by same letter differ significantly $(\mathrm{p}<0.05)$.

"Means in same row not followed by same letter differ significantly $(\mathrm{p}<0.05)$.

$\alpha$-pinene, sabinene $+B$-pinene, myrcene, and terpineol (Table 4). Other chemosystematic studies of volatile oils in Juniperus spp. support this finding (von Rudloff 1975, Straka 1993). Due to differences in oil composition within Juniperus spp., gas chromatography has been used as a taxonomic tool. Vasek and Scora (1967) were able to differentiate between species and subspecies of western North American junipers by utilizing this method. von Rudloff (1967) also found the components of the leaf oil of ashe junipers to be unique to that species when he used gas chromatography.

\section{Tree(Species*Sex)}

Alpha-pinene, camphene, limonene, camphor and bornyl acetate varied significantly among trees within species and sex (Table 2). Possible causes for these variations were differences in

Table 5. Concentrations ( $\mu \mathrm{g} / \mathrm{g}$ twig) of sabinene+ + -pinene, myrcene, and total oils in ashe and redberry junipers during 4 seasons averaged across male and female plants collected during 1991 at the Sonora Research Station.

\begin{tabular}{|c|c|c|c|}
\hline \multirow[b]{2}{*}{$\begin{array}{l}\text { Season \& } \\
\text { Species }\end{array}$} & \multicolumn{3}{|c|}{ Oils } \\
\hline & $\begin{array}{l}\text { Sabinenet } \\
\text { B-pinene }\end{array}$ & Myrcene & Total \\
\hline & \multicolumn{3}{|c|}{$\ldots$} \\
\hline \multicolumn{4}{|c|}{ 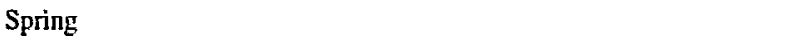 } \\
\hline Ashe & $0.40^{3}$ & $0.50^{3}$ & $9.18^{3}$ \\
\hline Redberty & $4.01^{b}$ & $0.90^{4}$ & $10.65^{a}$ \\
\hline \multicolumn{4}{|l|}{ Summer } \\
\hline Ashe & $0.02^{4}$ & $0.24^{\mathrm{a}}$ & $7.57^{\mathrm{a}}$ \\
\hline Redberry & $6.48^{b}$ & $1.30^{b}$ & $14.34^{\mathrm{b}}$ \\
\hline \multicolumn{4}{|l|}{ Fall } \\
\hline Ashe & $0.29^{3}$ & $0.23^{a}$ & $7.05^{3}$ \\
\hline Redberry & $2.63^{b}$ & $0.62^{b}$ & $6.90^{4}$ \\
\hline \multicolumn{4}{|l|}{ Winter } \\
\hline Ashe & $0.01^{\Delta}$ & $0.38^{a}$ & $6.2 S^{3}$ \\
\hline Redberry & $2.98^{\mathrm{b}}$ & $0.71^{a}$ & $7.42^{3}$ \\
\hline
\end{tabular}

\footnotetext{
theans for species within seasons and oils not followed by the same letter differ (p<0.05).
}

genetics, age, plant part, and environmental factors such as temperature, light, soil type, topography, and water availability.

Sex

There were no significant differences in volatile oil concentration between male and female junipers for any oils (Table 2). However, a significant interaction for species by sex for camphor resulted because male ashe juniper had a higher concentration than female; whereas, for redberry, female had a higher concentration than male. There was no obvious explanation for this interaction.

\section{Season}

A significant effect of season was found for total oils and for several of the individual oils (Table 2). Concentrations were generally highest during spring and summer. Adams $(1969,1970)$ found that both ashe and redberry juniper exhibited seasonal variations of volatile oils. Seasonal variations in oil production would probably be most affected by environmental factors of light, temperature, and rainfall and the phenology of the plants.

$A$ reduced model was run by season for sabinene $+B$-pinene myrcene, and total oils because significant season by species interactions were found (Table 5). Redberry had higher concentrations of sabinene $+\beta$-pinene in all seasons, and higher myrcene during summer and fall. Redberry had much higher total oils than ashe during the summer, but total oils did not differ significantly between species during the other seasons. Adams (1970) found that variability of redberry juniper oils was much greater during the summer than in winter months. He attributed this to higher metabolic activity during summer.

\section{Correlations}

Many significant positive and negative correlations were found between individual essential oils and between total oils and individual oils (Table 6). These correlations reflect primarily the differences between species since sex did not affect oil concentrations.

\section{Effect of Volatile Oils on Preference}

Some individual oils were positively and others negatively correlated with preference, across breeds and seasons. The 2 goat 
Table 6. Spearman's correlation coefficients for individual and total volatile oils in ashe and redberry juniper used for 1991 preference selection trials at the Sonora Research Station.

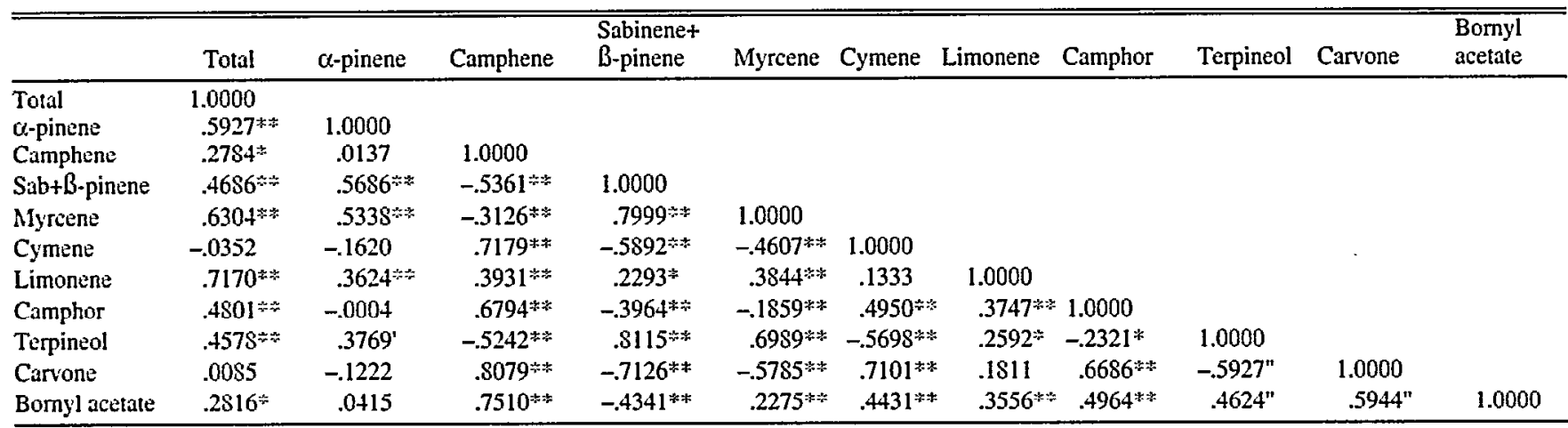

${ }^{*} * \approx$ Signititant at the 0.05 and 0.01 levels, respectively.

breeds exhibited similar correlations between individual oils and preference (Table 7). All oils were significantly correlated (either positive or negative) with grams of juniper consumed except limonene which was not significant with Spanish goats. The positive correlation of some oils, such as camphor, is probably a result of relative levels of oils in the 2 species. Choice was limited to juniper, so all choices contained these oils, but at different concentrations. A strong avoidance strategy would be related to negatively correlated oils. Goats probably selected juniper to avoid higher concentrations of negatively correlated oils, such as sabinene+B-pinene. There were significant negative correlations between the oils in the positive and negative categories (Table 6). Therefore, with the number of choices limited, goats strongly avoided the least palatable branches.

\section{Regression}

Grams consumed were regressed on individual oils by goat breed and combined goat breeds within and across seasons. Across goat breeds and seasons, the model $\mathrm{R}^{2}$ was 0.43 (Table 8 ). The combined regression contained 2 oils with negative coeffi-

Table 7. Spearman's correlation coefficients (r) across seasons for individual oils and grams consumed by breed.

\begin{tabular}{|c|c|c|c|}
\hline \multicolumn{2}{|l|}{ Angora } & \multicolumn{2}{|c|}{ Spanish } \\
\hline Oil & $\mathrm{r}$ & Oil & $r$ \\
\hline \multicolumn{4}{|c|}{ C..., } \\
\hline Camphene & $0.41 \%$ & Camphene & $0.58 * *$ \\
\hline Cymene & $0.35^{* 2 *}$ & Cymene & $0.59 \%$ \\
\hline Camphor & $0.25 *$ & Camphor & $0.41 * *$ \\
\hline Carvone & $0.40^{*}=$ & Carvone & $0.61 \div$ \\
\hline B. acetate ${ }^{1}$ & $0.32 \approx 2$ & B. acetate & $0.44 \div$ \\
\hline \multicolumn{4}{|c|}{. } \\
\hline Q-pinene & $-0.37+\cdots$ & $\alpha$-pinene & $-0.40=$ \\
\hline$S a b+\beta$-pinene $e^{2}$ & $-0.61 * *$ & Sab $+\beta$-pinene & $-0.74 \div$ \\
\hline Myrcene & -0.56 & Myrcene & $-0.65 * *$ \\
\hline Limonene & $-0.23 *$ & Terpineol & $-0.65 * \%$ \\
\hline Terpineol & $-0.54 \div$ & Total & $-0.33 * *$ \\
\hline Total & $-0.37 \div$ & & \\
\hline \multicolumn{4}{|c|}{ - No Effect- $-n_{-1}$} \\
\hline & & Limonene & -0.20 \\
\hline
\end{tabular}

$\because, *$ Signilicant at the 0.05 and 0.01 levels, respectively.

'B. acetate $=$ Bornyl acetate.

${ }^{2} \mathrm{~S} a \mathrm{~b}+\beta$ - $\mathrm{p}$ nene $\left.=\mathrm{S}\right\lrcorner$ binene+ $\beta$-pinene cients. Sabinene+ $\beta$-pinene accounted for the greater portion of the variation in grams consumed.

When grams consumed was regressed on oil concentrations within season, the $\mathrm{R}^{2}$ increased progressively for each season from spring (.24) to winter (.83) (Table 8). Myrcene, a negatively correlated oil, was the only significant oil during the spring. Myrcene and carvone, a positively correlated oil, entered the regressions for the summer. Sabinene $+\beta$-pinene was the most important oil during the fall and winter. Alpha-pinene entered the regression during the winter, but only accounted for $3 \%$ of the variation in grams consumed. These analyses indicate that the consumption of juniper was related to the concentration of individual essential oils.

Table 8. Stepwise regression of grams of juniper consumed on volatile oils for Angora and Spanish goats within seasons and across seasons during 1991 at the Sonora Research Station.

\begin{tabular}{|c|c|c|c|c|c|}
\hline Variable & Parameter & Prob. & $\begin{array}{c}\text { Standard } \\
\text { emor }\end{array}$ & $\begin{array}{c}\text { Partial } \\
\mathrm{R}^{2}\end{array}$ & $C(p)$ \\
\hline \multicolumn{6}{|c|}{ 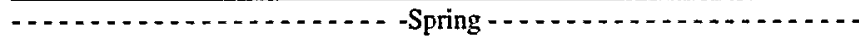 } \\
\hline Intercept & 41.93 & 0.0001 & 7.28 & & \\
\hline Myrcene & -6.95 & 0.0328 & 2.99 & .24 & \\
\hline Model $\mathrm{R}^{2}$ & & & & .24 & -2.86 \\
\hline \multicolumn{6}{|c|}{ - } \\
\hline Intercept & 25.07 & 0.0048 & 7.73 & & \\
\hline$\alpha$-pinene & -5.76 & 0.0687 & 2.96 & .11 & \\
\hline Carvone & 56.21 & 0.0058 & 17.82 & .38 & \\
\hline Model $\mathrm{R}^{2}$ & & & & .49 & -0.63 \\
\hline \multicolumn{6}{|c|}{ 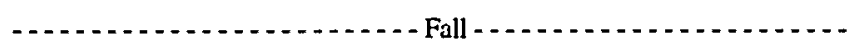 } \\
\hline Intercept & 36.07 & 0.0001 & 3.91 & & \\
\hline Sabinene+ $\beta$-pinene & le -3.23 & 0.0001 & 0.67 & .56 & \\
\hline Model $\mathrm{R}^{2}$ & & & & .56 & -1.75 \\
\hline
\end{tabular}

\begin{tabular}{lrllll} 
Intercept & 75.84 & 0.0001 & 7.43 & & \\
$\alpha$-pinene & -15.19 & 0.1052 & 8.87 & .03 & \\
Sabinene+ $\beta$-pinene & -4.07 & 0.0001 & 0.67 & .80 & \\
Model R2 & & & & .83 & 0.45 \\
& & & & & \\
& & & & & \\
Intercept & 38.23 & 0.0001 & 4.77 & & \\
Camphene & 7.10 & 0.0222 & 3.00 & .04 & \\
Sabinene+ $\beta$-pinene & -1.01 & 0.0016 & 0.31 & .25 & \\
Cymene & 3.60 & 0.0477 & 1.79 & .09 & \\
Limonene & -3.99 & 0.0009 & 1.16 & .05 & \\
Model R & & & & .43 & 2.92 \\
\hline
\end{tabular}




\section{Conclusions}

Spanish goats consumed more juniper than Angoras. Both breeds preferred ashe juniper over redberry juniper. Female plants were preferred over male plants during spring, summer, and fall when reproductive structures were present. Mean concentrations of volatile oils varied significantly betiveen species, and among seasons and individual trees, but not between sexes. Concentrations of total oils were greater during spring and summer than during fall and winter. Concentrations of sabinene+ $B$ pinene and myrcene were greater in redberry than in ashe juniper for all seasons. Individual oils were positively or negatively correlated with preference across seasons, with essentially no differences between goat breeds. Regression analyses indicated that concentrations of selected oils could be used to predict consumption of juniper.

\section{Management Implications}

With the loss of the wool and mohair incentive program by the U.S. government, there probably will be a short-term decrease in numbers of Angora goats. However, in Texas, interest in the production of Spanish, or meat type goats, is increasing. Since Spanish goats more readily consume juniper, this change will be beneficial for utilization and/or control of juniper on rangelands. For effective control of juniper, we recommend year-round moderate stocking rates and frequent use of pastures by goats. We also recommend temporary increases in goat numbers on pastures heavily infested with juniper during the winter months when the volatile oil concentrations are lowest and juniper is more palatable. When used in conjunction with other methods of brush control, such as fire, goats can aid in the control of juniper.

\section{Literature Cited}

Adams, R.A. 1969. Chemosystematic and numerical studies in natural populations of juniper. Ph.D. Diss. Univ. of Texas, Austin, Tex.

Adams, R.A. 1970. Seasonal variation of terpenoid constituents in natural populations of Juniperus pinchotii Sudw. Phytochemistry. 9:397402.

Barry, T.N. and B.J. Blaney. 1987. Secondary compounds in forages, p. 91-119. In: J.B. Hacker and J.H. Ternouth (eds), Nutrition of Herbivores. Academic Australia Press, Sidney.

Bryant, F.C., M.M. Kothmann, and L.B. Merrill. 1979. Diets of sheep, Angora goats, Spanish goats and whitetailed deer under excellent conditions. J. Range Manage. 32:412-417.

Bryant, F.C., G.K. Launchbaugh, and B.H. Koerth. 1983. Controlling mature Ashe juniper in Texas with crown fires. J. Range Manage. 36:165-168.

Bryant, J.P., F.D. Provenza, J. Pastor, P.B. Reichardt, T.P. Clausen, and J.T. du Toit. 1991. Interactions between woody plants and browsing mammals by secondary plant metabolites. Annu. Rev. Ecol. Sys. 22:431-436.

Clevenger, J.F. 1928. Apparatus for the determination of volatile oil. J. Amer. Pharm. Assoc. 17:345-349.

Fuhlendorf, S.D. 1992. Influence of age/size and grazing history on understory relationships of ashe juniper. M.S. Thesis. Texas A\&M Univ., College Station, Tex.

Gershenzon, J. and R. Croteau. 1991. Terpenoids, p. 165-219. In: G.A. Rosenthal and M.R. Berenbaum (eds), Herbivores: Their interactions with secondary plant metabolites. Academic Press Inc., San Diego, Calif.
Hatch, S.L., K.N. Gandhi, and L.E. Brown. 1990. Checklist of the vascular plants of Texas. Tex. Agr. Exp. Sta. Rep. MP-1655. College Station, Tex.

Huston, J.E. 1991. Goats and goat nutrition, p. 350-367.In: D.C. Church (ed), Livestock feeds and feeding. Prentice Hall, N.J.

Jobman, W.G. 1972. Consumption of juniper by deer and inhibition of rumen microorganisms by volatile oils of juniper. M.S. Thesis. Colorado State Univ., Fort Collins, Colo.

Maarse, H. and R.E. Kepner. 1970. Changes in composition of volatile terpenes in Douglas fir needles during maturation. J. Agr. Food Chem. 18:1095.

Merrill, L.B. and C.A. Taylor. 1976. Take note of the versatile goat. Rangeman's J. 3:74-76.

Nagy, J.G. and W. L. Regelin. 1977. Influence of plant volatile oils on food selection by animals. XIIIth Congr. of Game Biol. 13:225-229.

Owens, M.K., D.E. Spalenger, and L.A. Newton. 1992. Foraging behavior of goats in mixed brush communities of South Texas. pp. 112-117. Proceedings of the international conference on meat goat production and management \& marketing. J.C. Paschel and W.C. Hanselka (eds), Texas Agr. Ext. Serv. College Station, Tex.

Reichardt, P.B., J.P. Bryant, T.P. Clausen, and G.D. Wieland. 1984. Defense of winter-dormant Alaska paper birch against snowshoe hares. Oecologia 65:58-69.

Rykiel, E.J. and T.L. Cook. 1986. Hardwood-redcedar clusters in the post oak savanna of Texas. Southwest. Natur. 31:73-78.

Smeins, F.E. 1980. Natural role of fire on the Edwards Plateau, p. 4-16. In: L.D. White (ed), Prescribed burning on the Edwards Plateau of Texas. Texas Agr. Ext. Serv., College Station, Tex.

Smeins, F.E. 1990. Ashe juniper: Consumer of Edwards Plateau rangeland. Texas Agr. Exp. Sta. Tech. Rep. No, 90:1 Sonora Res. Sta., Sonora, Tex.

Smeins, F.E. and L.B. Merrill. 1988. Long-term change in a semi-arid grassland, p. 101-114. In: B.B. Amos and F.R. Gehibach (eds), Edwards Plateau vegetation: Plant ecological studies in central Texas. Baylor Univ. Press, Waco, Tex.

Smeins, F.E., T.W. Taylor, and L.B. Merrill. 1976. Vegetation of a 25year exclosure on the Edwards Plateau, Texas. J. Range Manage. 29:24-29.

Straka, E.J. 1993. Preferences for redberry and blueberry juniper exhibited by cattle, sheep and goats. M.S. Thesis. Texas A\&M Univ., College Station, Tex.

Taylor, Charles A., Jr. 1985. Multispecies grazing research overview. pp. 65-83. In: Proceedings of a conference on a multispecies grazing. F.H. Baker and C. Jones (eds), Winrock Int. Morrilton, Ark.

Taylor, C.A. Jr., T.D. Brooks, and N.E. Garza. 1993. Effects of short duration and high-intensity, low-frequency grazing systems on forage production and composition. J. Range Manage. 46:118-122.

Tucker, R.E. W. Majak, P.D. Parkinson, and A. McLean. 1976. Palatability of Douglas fir foliage to mule deer in relation to chemical and spatial factors. J. Range Manage. 29:486-489.

USDA-SCS. 1972. Technical guides section IIe, range site description, low stony hills range site, PE-19-25. Major land resource areas for the Edwards Plateau, Texas Soil Conservation Service, Temple, Tex.

Vasek, F.C. and R.W. Scora. 1967. Analysis of the oils of western North American junipers by gas liquid chromatography. Amer. J. Bot. 54:781-789.

von Rudloff, E. 1967. Gas-liquid chromatography of terpines. Part XIV. The volatile oil of the leaves of Juniperus ashei Buchholz. Can. J. Chem. 46:479-683.

von Rudloff, E. 1975. Chemisosystematic studies of volatile oils of $\mathbf{J}$. horizontalis. J. scopulorum, and J. virginiana. Phytochemistry 14:1319-1329.

Warren, L.E. , D.N. Ueckert, and J.M. Shelton. 1984. Comparative diets of Rambouillet, Barbado, and Karakul sheep and Spanish and Angora goats. J. Range Manage. 37:172-180.

Young, J.A., R.A. Evans, J.D. Birdy, and A. Torell. 1982. Cost of controlling maturing western juniper trees. J. Range Manage. 35:437-442.

Youngblood, B. and A.B. Cox. 1992. An economic study of a typical ranching area on the Edwards Plateau in Texas. Texas Agr. Exp. Sta. Bull. 297. 